\title{
Kongens fortjenstmedalje til Harald Lystad
}

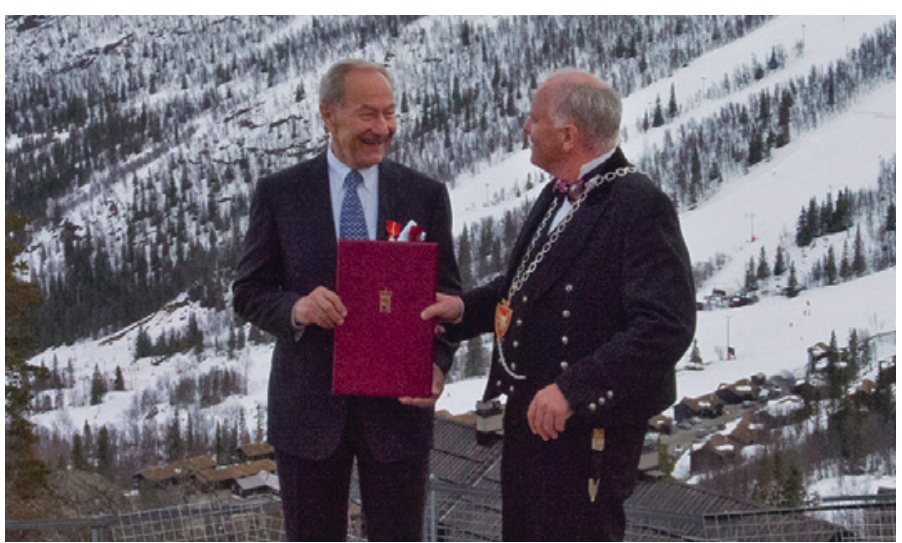

Harald Lystad får overrakt medaljen av ordføreren i Hemsedal kommune, Oddvar Grøthe. Foto Liv Torunn Torpe
Harald Lystad (f. 1944), fastlege og kommuneoverlege i Hemsedal, er tildelt Kongens fortjenstmedalje i sølv for sitt arbeid med å forebygge skiulykker.

Han startet sin legegjerning som distriktslege i Lofoten fra 1971 til 1975, og deretter, siden 1975, har han vært i Hemsedal, først som distriktslege og siden 1984 som fastlege og kommuneoverlege.

Lystad er regnet som en av Norges fremste eksperter på skiuhell og har utgitt flere artikler om alpine skiskader. Helt fra 1977 har han bygd opp et register over slike skader.

Han tok medisinsk embetseksamen i Bergen i 1970 og ble godkjent spesialist i allmennmedisin i 1985 og i samfunnsmedisin i 1987. Han er dessuten godkjent flylege, ved siden av å være en ivrig privatflyver.

\section{Gunn Marit Seberg}

Tidsskriftet 